\title{
The Al-Rich Part of the Fe-Al Phase Diagram
}

\author{
Xiaolin Li, Anke Scherf, Martin Heilmaier, and Frank Stein
}

(Submitted October 30, 2015; in revised form November 27, 2015; published online January 19, 2016)

\begin{abstract}
The Al-rich part of the Fe-Al phase diagram between 50 and 80 at.\% $\mathrm{Al}$ including the complex intermetallic phases $\mathrm{Fe}_{5} \mathrm{Al}_{8}(\varepsilon), \mathrm{FeAl}_{2}, \mathrm{Fe}_{2} \mathrm{Al}_{5}$, and $\mathrm{Fe}_{4} \mathrm{Al}_{13}$ was re-investigated in detail. A series of 19 alloys was produced and heat-treated at temperatures in the range from 600 to $1100{ }^{\circ} \mathrm{C}$ for up to $5000 \mathrm{~h}$. The obtained data were further complemented by results from a number of diffusion couples, which helped to determine the homogeneity ranges of the phases $\mathrm{FeAl}_{2}$, $\mathrm{Fe}_{2} \mathrm{Al}_{5}$, and $\mathrm{Fe}_{4} \mathrm{Al}_{13}$. All microstructures were inspected by scanning electron microscopy (SEM), and chemical compositions of the equilibrium phases as well as of the alloys were obtained by electron probe microanalysis (EPMA). Crystal structures and the variation of the lattice parameters were studied by $x$-ray diffraction (XRD) and differential thermal analysis (DTA) was applied to measure all types of transition temperatures. From these results, a revised version of the Al-rich part of the phase diagram was constructed.
\end{abstract}

Keywords differential thermal analysis (DTA), diffusion couples, electron probe microanalysis (EPMA), intermetallics, phase diagram, phase transformation

\section{Introduction and Literature Review}

Many investigations were done in the Fe-Al system since the 1920 s regarding its capability as a replacement for steels due to the outstanding oxidation resistance at high temperatures and to the low density of Fe-Al based alloys. ${ }^{[1-3]}$ These properties, which should improve with increasing $\mathrm{Al}$ content, strongly contribute to its candidate role as a high temperature structural material. However, the Al-rich part of the $\mathrm{Fe}-\mathrm{Al}$ phase diagram with $>50$ at. $\% \mathrm{Al}$ has not yet been finally determined. Five different intermetallic phases were identified by previous studies in this composition range, and their crystal structure details are listed in Table 1. The FeAl phase has a simple cubic (B2-type) crystal structure, whereas the Al-rich intermetallic phases $\mathrm{FeAl}_{2}, \mathrm{Fe}_{2} \mathrm{Al}_{5}$, and $\mathrm{Fe}_{4} \mathrm{Al}_{13}$ have complex structures of the triclinic, orthorhombic and monoclinic type, respectively. ${ }^{1}$ The high-temperature phase $\mathrm{Fe}_{5} \mathrm{Al}_{8}$, which was designated only as $\varepsilon$ phase in the literature due to its for long time unknown structure, decomposes on cooling in a rapid eutectoid reaction and cannot be quenched to room temperature. Therefore, its crystal structure was determined only recently

Xiaolin Li and Frank Stein, Max Planck-Institut für Eisenforschung GmbH, Düsseldorf, Germany; Anke Scherf and Martin Heilmaier, Institute for Applied Materials (IAM-WK), Karlsruhe Institute of Technology (KIT), Karlsruhe, Germany. Contact e-mail: x.li@mpie.de.

\footnotetext{
${ }^{1}$ It should be mentioned that the phase $\mathrm{Fe}_{4} \mathrm{Al}_{13}$ originally was denoted as $\mathrm{FeAl}_{3}$ in the old literature, even though already in $1955 \mathrm{Black}^{[10]}$ found that the true composition corresponds to a formula $\mathrm{Fe}_{4} \mathrm{Al}_{13}$. Only since Grin et al. ${ }^{[9]}$ published their structure refinement of this phase in 1994, the formula $\mathrm{Fe}_{4} \mathrm{Al}_{13}$ is generally accepted in the literature.
}

and was found to be of the body-centered cubic $\mathrm{Cu}_{5} \mathrm{Zn}_{8}$ type. ${ }^{[5,6]}$

The equilibrium diagram of the $\mathrm{Fe}-\mathrm{Al}$ system in the range between 50 and 100 at.\% $\mathrm{Al}$ was initially studied already in the $20 \mathrm{~s}$ and $30 \mathrm{~s}$ of the last century. ${ }^{[1-17]}$ During the following about 80 years, only comparatively few more data were published contributing to this part of the phase diagram. ${ }^{[18-24]}$ All available information was carefully assessed by Kubaschewski ${ }^{[25]}$ and later on in the comprehensive overview of Kattner and Burton ${ }^{[26]}$ that provides the most commonly used version of the Fe-Al phase diagram. More recent assessments of the experimental data were published by Burkhardt et al. ${ }^{[27]}$ (however not containing a plotted phase diagram) and, most recently, by Turchanin et al. ${ }^{[28]}$ The phase diagram in the latter publication is qualitatively identical to the version of Kattner and Burton, but some invariant reaction temperatures were corrected using DTA results provided by Stein and Palm. ${ }^{[29]}$

Figure 1(a) shows the Al-rich Fe-Al phase diagram as assessed by Kattner and Burton ${ }^{[26]}$ including all relevant experimental data from the literature, and Fig. 1(b) presents a magnification of the high-temperature part of the diagram in the range between 50 and 90 at.\% Al clearly revealing a strong scatter of the experimental data. This applies to the liquidus and all invariant reaction temperatures as well as to the homogeneity ranges of all occurring intermetallic phases as is briefly described in the following:

There is general agreement in the literature that the hightemperature phase $\mathrm{Fe}_{5} \mathrm{Al}_{8}$ forms peritectically from the liquid and $\mathrm{FeAl}$ and decomposes by a eutectoid reaction into $\mathrm{FeAl}$ and $\mathrm{FeAl}_{2}$. The literature values obtained from thermal analysis for the reaction temperatures vary strongly ranging from 1207 to $1232{ }^{\circ} \mathrm{C}$ for the peritectic reaction and from 1080 to $1103{ }^{\circ} \mathrm{C}$ for the eutectoid reaction. ${ }^{[13,14,16,19,21,29]}$ This significant scatter in the invariant reaction temperatures is also reflected in the differing values reported in the four assessments, ${ }^{[25-28]}$ see Table 2. For comparison, also calculated data from thermodynamic modelling applying the CALPHAD approach are given (Table 3). ${ }^{[30-33]}$ 
Table 1 Intermetallic phases and their crystal structures

\begin{tabular}{|c|c|c|c|c|c|}
\hline Phase & Pearson symbol & Space group & Prototype & Lattice parameters, $\mathbf{n m}$ & Ref \\
\hline $\mathrm{FeAl}$ & $c P 2$ & $\operatorname{Pm} \overline{3} m$ & $\mathrm{CsCl}$ & $a=0.29080$ & 4 \\
\hline $\mathrm{Fe}_{5} \mathrm{Al}_{8}$ & $c I 52$ & $I \overline{4} 3 m$ & $\mathrm{Cu}_{5} \mathrm{Zn}_{8}$ & $\begin{array}{l}a=0.89757 \\
\left(\text { at } 1120^{\circ} \mathrm{C} \text { ) }\right.\end{array}$ & 5,6 \\
\hline $\mathrm{FeAl}_{2}$ & $a P 19$ & $P \overline{1}$ & $\mathrm{FeAl}_{2}$ & $\begin{array}{l}a=0.48745 \\
b=0.64545 \\
c=0.87361 \\
\alpha=87.930^{\circ} \\
\beta=74.396^{\circ} \\
\gamma=83.062^{\circ}\end{array}$ & 7 \\
\hline $\mathrm{Fe}_{2} \mathrm{Al}_{5}$ & $o C 24$ & $\mathrm{Cmcm}$ & $\mathrm{Fe}_{2} \mathrm{Al}_{5}$ & $\begin{array}{l}a=0.76559 \\
b=0.64154 \\
c=0.42184\end{array}$ & 8 \\
\hline $\mathrm{Fe}_{4} \mathrm{Al}_{13}$ & $m C 102$ & $C 2 / m$ & $\mathrm{Fe}_{4} \mathrm{Al}_{13}$ & $\begin{array}{c}a=1.5492 \\
b=0.8078 \\
\mathrm{c}=1.2471 \\
\beta=107.69^{\circ}\end{array}$ & 9 \\
\hline
\end{tabular}

$\mathrm{Fe}_{5} \mathrm{Al}_{8}$ and $\mathrm{Fe}_{2} \mathrm{Al}_{5}$ form a eutectic at 68-69 at.\% $\mathrm{Al}$ and at a temperature in the range $1153{ }^{\circ} \mathrm{C}^{[15]}$ to $1166^{\circ} \mathrm{C}^{[14]}$ Only few degrees below this temperature, $\mathrm{FeAl}_{2}$ forms in a peritectoid reaction from the phases $\mathrm{Fe}_{5} \mathrm{Al}_{8}$ and $\mathrm{Fe}_{2} \mathrm{Al}_{5}$. The scatter in the reported experimental reaction temperatures is similar as above, but the temperature interval between these two reactions is always about $10{ }^{\circ} \mathrm{C}$ (see also Table 2). This is worth to be mentioned because this finding is quite different from results of thermodynamic modelling, which in all cases give a much smaller interval of only $1-2{ }^{\circ} \mathrm{C}$ (see Table 3 listing calculated reaction temperatures).

There is some controversy in the literature about the reaction type of the formation of $\mathrm{Fe}_{4} \mathrm{Al}_{13}$. The question is whether the phase forms peritectically ( $\mathrm{L}+\mathrm{Fe}_{2} \mathrm{Al}_{5} \leftrightarrow$ $\left.\mathrm{Fe}_{4} \mathrm{Al}_{13}\right)^{[15,21]}$ or congruently from the melt $(\mathrm{L} \leftrightarrow$ $\left.\mathrm{Fe}_{4} \mathrm{Al}_{13}\right) .{ }^{[14,19,22]}$ Most of the assessments tend to the peritectic version (see e.g. Tables 2 and 3). In any case, the respective peritectic/eutectic composition will be very near to that of the melting point of $\mathrm{Fe}_{4} \mathrm{Al}_{13}$., as is also indicated in Kattner and Burton's version, see Fig. 1(b).

Information about the homogeneity ranges of the different phases is only very scarce in the literature. For the hightemperature phase $\mathrm{Fe}_{5} \mathrm{Al}_{8}$, Kattner and Burton ${ }^{[26]}$ estimate a composition range from $\approx 58$ to $\approx 65$ at. $\% \mathrm{Al}$. The homogeneity ranges of the Al-richer phases $\mathrm{FeAl}_{2}, \mathrm{Fe}_{2} \mathrm{Al}_{5}$, and $\mathrm{Fe}_{4} \mathrm{Al}_{13}$ are much smaller. In Kattner and Burton's assessment, widths of 0.9 at. $\%$ (66.0 to 66.9 at. $\% \mathrm{Al}$ ), 3 at.\% (70 to 73 at.\% $\mathrm{Al}$ ), and 2.1 at.\% (74.5 to 76.6 at.\% $\mathrm{Al}$ ), respectively, are reported. ${ }^{[26]}$ In a more recent study on the Fe-Al-Zr phase diagram, ${ }^{[34]}$ values of $1.8,2.2,0.7$ at. $\%$ were given for the widths of the homogeneity ranges of these intermetallic compounds at $1000{ }^{\circ} \mathrm{C}$.

Summarizing the above and having in mind that several lines in the Al-rich part of the Fe-Al phase diagram are still drawn as dotted lines today, it can be stated that this part of the Fe-Al system deserves more detailed investigations. Therefore, in the present work a series of $\mathrm{Fe}-\mathrm{Al}$ alloys with 57 to 79 at.\% $\mathrm{Al}$ was produced and measured by DTA to obtain all reaction temperatures. Selected alloys were heattreated in the range from 600 to $1100{ }^{\circ} \mathrm{C}$ for up to $5000 \mathrm{~h}$ to study the resulting microstructures and phase equilibria by SEM and EPMA. In addition, a number of diffusion couples made of Fe-50Al (alloy compositions are given in at.\% throughout this paper) and pure $\mathrm{Al}$ were produced to get further information about the homogeneity ranges of $\mathrm{FeAl}_{2}$, $\mathrm{Fe}_{2} \mathrm{Al}_{5}$ and $\mathrm{Fe}_{4} \mathrm{Al}_{13}$ phases. Crystal structures and lattice parameter variations were studied by XRD. By combining all experimental results, a revised phase diagram was finally constructed.

\section{Experimental}

A series of Fe-Al binary alloys with nominal compositions between 57 and 79 at.\% $\mathrm{Al}$ was produced from high purity $\mathrm{Fe}(99.98$ wt.\%) and $\mathrm{Al}(99.99$ wt.\%) by vacuum induction melting or levitation melting with casting into a cold copper mould, or by arc melting (Table 4). In all cases, these processes were performed in pure argon. EPMA was applied to determine the actual chemical compositions of all alloys. The analyzed compositions, which are listed in Table 4, were found to agree with the nominal compositions within 1.0 at.\% Al. Pieces of each alloy were cut by electrical discharge machining (EDM) and encapsulated in quartz tubes back-filled with argon and were heat-treated at different temperatures for times as given in Table 4. Besides the series of cast alloys, three diffusion couples between an $\mathrm{Fe}-50 \mathrm{Al}$ alloy and pure $\mathrm{Al}$ were prepared and heat-treated at $620{ }^{\circ} \mathrm{C}$ (solid-solid diffusion couple), 800 and $850{ }^{\circ} \mathrm{C}$ (solid-liquid diffusion couples) in an $\mathrm{Ar}$ atmosphere. The first diffusion couple consisted of $5 \times 5 \times 10 \mathrm{~mm}^{3}$ cuboid shaped parts which were connected to each other directly with light pressure by using Mo clamps. The second diffusion couple was made of one pure Al cylinder of $8 \mathrm{~mm}$ 

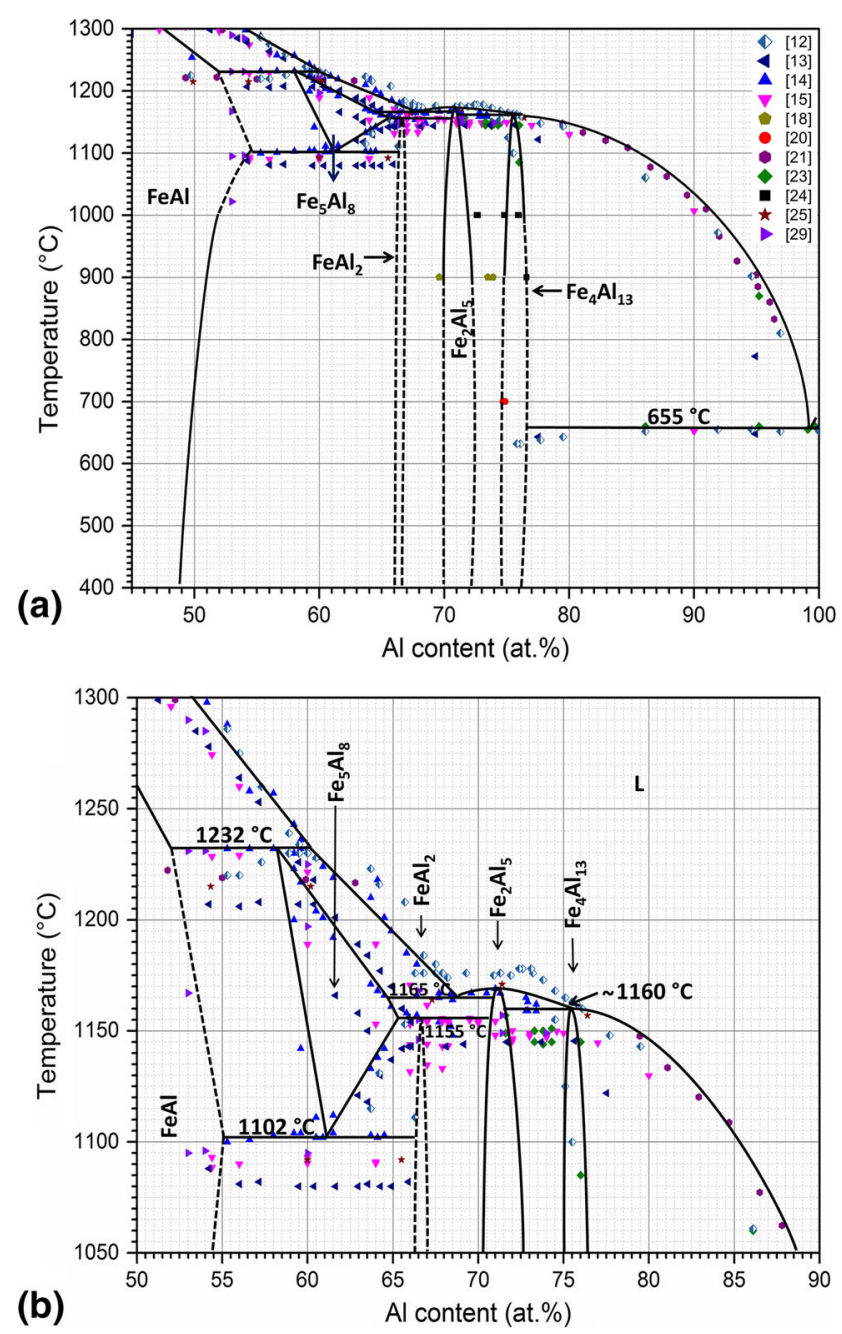

Fig. 1 (a) Experimental data from the literature ${ }^{[12-15,18,20,21,23-25,29]}$ and evaluated Al-rich Fe-Al phase diagram from Kattner and Bur$\operatorname{ton}^{[26]}$ (solid and dashed lines) (b) magnification of the high-temperature part between $50-90$ at.\% $\mathrm{Al}$ in diameter and $8 \mathrm{~mm}$ in height, which was pressed in a cylinder-shaped hole with the same dimensions in a block of Fe-50Al alloy. The whole assembly was covered with a $5 \mathrm{~mm}$ thick lid made of the Fe-50Al alloy, placed in an alumina crucible, and completely covered with alumina powder. On top of the alumina powder, some Ti filings were added as an oxygen getter. The third diffusion couple was made of two cylinders of pure $\mathrm{Al}$ and Fe-50Al alloy (both $18 \mathrm{~mm}$ in diameter and $10 \mathrm{~mm}$ in height) with the Fe-50Al cylinder placed on top of the pure Al piece inside an alumina crucible. Again this diffusion couple was covered with alumina powder and $\mathrm{Ti}$ filings were used as getter material. All diffusion couples were furnace-cooled. More information on heat treatment times and observed phase layers is given in Table 5 .

Microstructures were studied by scanning electron microscopy (SEM) using a JEOL-6490 instrument with a working distance of $10 \mathrm{~mm}$. Chemical compositions of individual phases were established by wavelength dispersive spectrometry (WDS) carried out on an EPMA JEOL JXA-8100. The instrument was operated at $15 \mathrm{kV}$ and $20 \mathrm{nA}$. The pure elements were used as standards. Crystal structures of the phases were identified by XRD of powdered samples, which were easily obtained by crushing in a steel mortar. On a Seifert ID 3003 x-ray diffraction instrument, the $2 \theta$ range from $20^{\circ}$ to $130^{\circ}$ was scanned using $\mathrm{Co}-\mathrm{K}_{\alpha 1}$ radiation $(\lambda=0.17890 \mathrm{~nm})$. The program CaRine Crystallography 3.1 (Divergent S.A., Compiègne, France) was used to calculate theoretical XRD patterns in order to compare them with the experimental results, and lattice parameters were refined by using the least-squares fitting software LCLSQ 8.5 (C.W. Burnham, Harvard University, 1993). DTA was performed on a Setaram SETSYS-18 instrument. Cylindrical samples with $3 \mathrm{~mm}$ in diameter and $3 \mathrm{~mm}$ in height were placed into alumina crucibles and heated under argon at rates of 1,5 , and $10{ }^{\circ} \mathrm{C} /$ min. The accuracy of the temperature calibration is $\pm 1{ }^{\circ} \mathrm{C}$. Each sample was heated and cooled at least twice to check the reproducibility of the results.

Table 2 Invariant reaction temperatures in the Al-rich part of the Fe-Al system as assessed from the available literature data ${ }^{[25-28]}$

\begin{tabular}{|c|c|c|c|c|c|}
\hline \multirow[b]{2}{*}{ Invariant reaction } & \multicolumn{4}{|c|}{ Reaction temperature as assessed from available experimental literature data, ${ }^{\circ} \mathrm{C}$} & \multirow{2}{*}{$\begin{array}{c}\text { Reaction } \\
\text { temperature from } \\
\text { this work, }{ }^{\circ} \mathrm{C}\end{array}$} \\
\hline & Kubaschewski $^{[25]}$ & $\begin{array}{l}\text { Kattner and } \\
\text { Burton }^{[26]}\end{array}$ & $\begin{array}{l}\text { Burkhardt } \\
\text { et al. }{ }^{[27]}\end{array}$ & $\begin{array}{l}\text { Turchanin } \\
\text { et al. }{ }^{[28]}\end{array}$ & \\
\hline $\mathrm{L}+\mathrm{FeAl} \leftrightarrow \mathrm{Fe}_{5} \mathrm{Al}_{8}$ & 1215 & 1232 & 1229 & 1231 & 1231 \\
\hline $\mathrm{L} \leftrightarrow \mathrm{Fe}_{2} \mathrm{Al}_{5}$ & 1171 & 1169 & 1156 & 1157 & $\approx 1158$ \\
\hline $\mathrm{L} \leftrightarrow \mathrm{Fe}_{5} \mathrm{Al}_{8}+\mathrm{Fe}_{2} \mathrm{Al}_{5}$ & 1164 & 1165 & 1153 & 1155 & 1155 \\
\hline $\mathrm{L}+\mathrm{Fe}_{2} \mathrm{Al}_{5} \leftrightarrow \mathrm{Fe}_{4} \mathrm{Al}_{13}$ & 1157 & $\approx 1160$ & 1152(a) & 1149 & 1150 \\
\hline $\mathrm{Fe}_{5} \mathrm{Al}_{8}+\mathrm{Fe}_{2} \mathrm{Al}_{5} \leftrightarrow \mathrm{FeAl}_{2}$ & 1153 & 1156 & 1144 & 1146 & 1145 \\
\hline $\mathrm{Fe}_{5} \mathrm{Al}_{8} \leftrightarrow \mathrm{FeAl}+\mathrm{FeAl}_{2}$ & 1092 & 1102 & 1093 & 1095 & 1095 \\
\hline $\mathrm{L} \leftrightarrow \mathrm{Fe}_{4} \mathrm{Al}_{13}+(\mathrm{Al})$ & 652 & 655 & 655 & 655 & 654 \\
\hline
\end{tabular}

Temperatures measured in the present study are given in the last column. (a) Assuming congruent melting of $\mathrm{Fe}_{4} \mathrm{Al}_{13}$ 
Table 3 Invariant reaction temperatures in the Al-rich part of the Fe-Al system as obtained from thermodynamic modelling based on the CALPHAD approach ${ }^{[30-33]}$

\begin{tabular}{|c|c|c|c|c|}
\hline \multirow[b]{2}{*}{ Invariant reaction } & \multicolumn{4}{|c|}{ Reaction temperature from CALPHAD modelling, ${ }^{\circ} \mathrm{C}$} \\
\hline & Seierstein $^{[30]}$ & Du et al. ${ }^{[31]}$ & Sundman et al. ${ }^{[32]}$ & Jacobs and Schmid-Fetzer ${ }^{[33]}$ \\
\hline $\mathrm{L}+\mathrm{FeAl} \leftrightarrow \mathrm{Fe}_{5} \mathrm{Al}_{8}$ & 1222 & 1222 & 1226 & 1228 \\
\hline $\mathrm{L} \leftrightarrow \mathrm{Fe}_{2} \mathrm{Al}_{5}$ & 1161 & 1158 & $\ldots$ & 1162 \\
\hline $\mathrm{L} \leftrightarrow \mathrm{Fe}_{5} \mathrm{Al}_{8}+\mathrm{Fe}_{2} \mathrm{Al}_{5}$ & 1157 & 1155 & 1154 & 1157 \\
\hline $\mathrm{L}+\mathrm{Fe}_{2} \mathrm{Al}_{5} \leftrightarrow \mathrm{Fe}_{4} \mathrm{Al}_{13}$ & 1151 & $1155(\mathrm{a})$ & 1151 & 1151 \\
\hline $\mathrm{Fe}_{5} \mathrm{Al}_{8}+\mathrm{Fe}_{2} \mathrm{Al}_{5} \leftrightarrow \mathrm{FeAl}_{2}$ & 1155 & 1153 & 1153 & 1155 \\
\hline $\mathrm{Fe}_{5} \mathrm{Al}_{8} \leftrightarrow \mathrm{FeAl}+\mathrm{FeAl}_{2}$ & 1095 & 1094 & 1089 & $1084 / 1065(b)$ \\
\hline $\mathrm{L} \leftrightarrow \mathrm{Fe}_{4} \mathrm{Al}_{13}+(\mathrm{Al})$ & 654 & 654 & 654 & 654 \\
\hline
\end{tabular}

(a) Assuming congruent melting of $\mathrm{Fe}_{4} \mathrm{Al}_{13}$. (b) Results of two different models

\section{Results and Discussion}

\subsection{Stability and Homogeneity Range of the High- Temperature Phase $\mathrm{Fe}_{5} \mathrm{Al}_{8}$ (\& Phase)}

Three representative microstructures of as-cast alloys with compositions in the range of the $\mathrm{Fe}_{5} \mathrm{Al}_{8}$ phase are shown in Fig. 2. The dependence of the as-cast microstructures on the $\mathrm{Al}$ content in this composition range was already described in our previous paper. ${ }^{[35]}$ The alloys consist of the phases $\mathrm{FeAl}$ and $\mathrm{FeAl}_{2}$ and contain a finescaled lamellar matrix of these two phases as a result of the rapid eutectoid decomposition of $\mathrm{Fe}_{5} \mathrm{Al}_{8}$ phase during cooling. ${ }^{[5]}$ Alloys with less $\mathrm{Al}$ than the eutectoid value additionally contain (pre-eutectoid) FeAl particles (Fig. 2a), while alloys with Al contents above this limit show certain amounts of $\mathrm{FeAl}_{2}$ (Fig. 2c). As-cast Fe-60.9Al shows a fully lamellar microstructure with an average lamellar spacing of about $200 \mathrm{~nm}$ (Fig. 2b and d). It must be mentioned here that the values given for the alloy compositions in Ref 35 partially are slightly different from the present ones. Data in Ref 35 were from wet chemical analysis of separate alloy pieces, while in the present study all given compositions, i.e. phase as well as alloy compositions, are directly from EPMA analysis of the investigated samples. With the latter results, the composition of the eutectoid point is determined as 60.9 at. $\% \mathrm{Al}$.

The composition of the Al-poor and -rich limit of the homogeneity range of $\mathrm{Fe}_{5} \mathrm{Al}_{8}$ cannot be directly measured but can be extrapolated from the DTA results. Figure 3 shows the $\mathrm{Fe}_{5} \mathrm{Al}_{8}$ phase region of the $\mathrm{Fe}-\mathrm{Al}$ phase diagram as obtained by the present DTA experiments. The reaction temperatures for the peritectic formation and eutectoid decomposition are 1231 and $1095{ }^{\circ} \mathrm{C}$, respectively. Both, the entrance and exit of the $\mathrm{Fe}_{5} \mathrm{Al}_{8}$ single-phase field can be well measured by DTA giving the shape of the phase field as shown in Fig. 3. From this information, the homogeneity range of $\mathrm{Fe}_{5} \mathrm{Al}_{8}$ is found to extend from 56.0 to 64.5 at.\% Al.

\subsection{Liquidus and Invariant Reactions of $\mathrm{FeAl}_{2}, \mathrm{Fe}_{2} \mathrm{Al}_{5}$ and $\mathrm{Fe}_{4} \mathrm{Al}_{13}$ Phases}

Some representative as-cast microstructures of $\mathrm{Fe}-\mathrm{Al}$ alloys in the composition range from 67 to 79 at.\% $\mathrm{Al}$ are shown in Fig. 4 and 5. The microstructure of the as-cast alloy Fe-66.8Al (Fig. 4a), which should be single-phase $\mathrm{FeAl}_{2}$ in the equilibrium state at room temperature, contains three different phases FeAl (light contrast in BSE mode), $\mathrm{FeAl}_{2}$ (grey), and $\mathrm{Fe}_{2} \mathrm{Al}_{5}$ (dark). This observation can be well explained by the fact that $\mathrm{FeAl}_{2}$ does not form congruently from the melt but in the solid state in a peritectoid type of reaction. Coming from the liquid state, the first solidification step is the precipitation of $\mathrm{Fe}_{5} \mathrm{Al}_{8}$ phase, which in a later stage of cooling transforms into a fine mixture of $\mathrm{FeAl}+\mathrm{FeAl}_{2}$ (white-grey mixture in the core of the grains). The rest of the liquid solidifies eutectically into $\mathrm{Fe}_{5} \mathrm{Al}_{8}$ and $\mathrm{Fe}_{2} \mathrm{Al}_{5}$ and only then, in the completely solidified state, $\mathrm{FeAl}_{2}$ grows peritectoidally between the two phases $\mathrm{Fe}_{5} \mathrm{Al}_{8}$ and $\mathrm{Fe}_{2} \mathrm{Al}_{5}$. As Fig. 4(b) shows and as is expected from the phase diagram, this threephase as-cast microstructure transforms completely to single-phase $\mathrm{FeAl}_{2}$ by heat treatment at elevated temperatures.

As mentioned in the introduction, there is still uncertainty about the reaction type leading to the formation of $\mathrm{Fe}_{4} \mathrm{Al}_{13}$ (peritectic or congruent). In case this phase forms congruently from the melt, there must be a eutectic between $\mathrm{Fe}_{2} \mathrm{Al}_{5}$ and $\mathrm{Fe}_{4} \mathrm{Al}_{13}$. The as-cast microstructure of the alloy $\mathrm{Fe}-72.9 \mathrm{Al}$ in Fig. 4(c) shows $\mathrm{Fe}_{2} \mathrm{Al}_{5}$ primary dendrites embedded in an $\mathrm{Fe}_{4} \mathrm{Al}_{13}$ matrix. There are no indications of a eutectic reaction. Therefore, either the eutectic point is extremely near to the congruent melting point or the reaction is of the peritectic type. As there are no indications of a eutectic, we stick with the peritectic version. In Fig. 5(a), the as-cast microstructure of the alloy Fe-74.2Al is presented. It does not show any $\mathrm{Fe}_{2} \mathrm{Al}_{5}$ phase and appears completely single-phase $\mathrm{Fe}_{4} \mathrm{Al}_{13}$. This is also true for the ascast alloys Fe-74.5Al and Fe-74.9Al (see also Table 4). 
Table 4 Analyzed compositions (EPMA), type of melting and conditions and phases of the investigated Fe-Al samples (VIM: vacuum induction melting, LM: levitation melting, AM: arc melting)

\begin{tabular}{|c|c|c|c|}
\hline Actual composition, at.\% & Type of melting & Condition & Phase content \\
\hline $\mathrm{Fe}-57.3 \mathrm{Al}$ & VIM & As-cast & $\mathrm{FeAl}+\mathrm{FeAl}_{2}$ \\
\hline $\mathrm{Fe}-59.0 \mathrm{Al}$ & VIM & $\begin{array}{l}\text { As-cast } \\
1000^{\circ} \mathrm{C} / 216 \mathrm{~h}\end{array}$ & $\mathrm{FeAl}+\mathrm{FeAl}_{2}$ \\
\hline $\mathrm{Fe}-59.7 \mathrm{Al}$ & VIM & $\begin{array}{l}\text { As-cast } \\
900{ }^{\circ} \mathrm{C} / 168 \mathrm{~h}\end{array}$ & $\mathrm{FeAl}+\mathrm{FeAl}_{2}$ \\
\hline $\mathrm{Fe}-60.9 \mathrm{Al}$ & VIM & $\begin{array}{l}\text { As-cast } \\
800{ }^{\circ} \mathrm{C} / 48 \mathrm{~h} \\
1000{ }^{\circ} \mathrm{C} / 36 \mathrm{~h}\end{array}$ & $\mathrm{FeAl}+\mathrm{FeAl}_{2}$ \\
\hline $\mathrm{Fe}-61.2 \mathrm{Al}$ & VIM & As-cast & $\mathrm{FeAl}+\mathrm{FeAl}_{2}$ \\
\hline $\mathrm{Fe}-62.6 \mathrm{Al}$ & VIM & $\begin{array}{l}\text { As-cast } \\
1000{ }^{\circ} \mathrm{C} / 6 \mathrm{~h}\end{array}$ & $\mathrm{FeAl}+\mathrm{FeAl}_{2}$ \\
\hline $\mathrm{Fe}-63.6 \mathrm{Al}$ & VIM & $\begin{array}{l}\text { As-cast } \\
800{ }^{\circ} \mathrm{C} / 500 \mathrm{~h} \\
600{ }^{\circ} \mathrm{C} / 1856 \mathrm{~h}\end{array}$ & $\mathrm{FeAl}+\mathrm{FeAl}_{2}$ \\
\hline $\mathrm{Fe}-64.4 \mathrm{Al}$ & $\mathrm{AM}$ & As-cast & $\mathrm{FeAl}+\mathrm{FeAl}_{2}$ \\
\hline $\mathrm{Fe}-66.8 \mathrm{Al}$ & LM & $\begin{array}{l}\text { As-cast } \\
900{ }^{\circ} \mathrm{C} / 840 \mathrm{~h}\end{array}$ & $\begin{array}{l}\mathrm{FeAl}+\mathrm{FeAl}_{2}+\mathrm{Fe}_{2} \mathrm{Al}_{5} \\
\mathrm{FeAl}_{2}\end{array}$ \\
\hline $\mathrm{Fe}-68.0 \mathrm{Al}$ & VIM & $\begin{array}{l}\text { As-cast } \\
600{ }^{\circ} \mathrm{C} / 5000 \mathrm{~h} \\
800{ }^{\circ} \mathrm{C} / 200 \mathrm{~h} \\
1000{ }^{\circ} \mathrm{C} / 100 \mathrm{~h} \\
1100{ }^{\circ} \mathrm{C} / 50 \mathrm{~h}\end{array}$ & $\mathrm{FeAl}_{2}+\mathrm{Fe}_{2} \mathrm{Al}_{5}$ \\
\hline \multirow[t]{2}{*}{$\mathrm{Fe}-69.4 \mathrm{Al}$} & VIM & As-cast & $\begin{array}{l}\mathrm{Fe}_{2} \mathrm{Al}_{5} \text { with very low volume } \\
\text { fraction of } \mathrm{FeAl}_{2}(<1 \text { vol.\%) }\end{array}$ \\
\hline & & $\begin{array}{l}800{ }^{\circ} \mathrm{C} / 200 \mathrm{~h} \\
1000^{\circ} \mathrm{C} / 100 \mathrm{~h}\end{array}$ & $\mathrm{FeAl}_{2}+\mathrm{Fe}_{2} \mathrm{Al}_{5}$ \\
\hline $\mathrm{Fe}-70.3 \mathrm{Al}$ & $\mathrm{AM}$ & As-cast & $\mathrm{Fe}_{2} \mathrm{Al}_{5}$ \\
\hline $\mathrm{Fe}-71.7 \mathrm{Al}$ & LM & As-cast & $\mathrm{Fe}_{2} \mathrm{Al}_{5}$ \\
\hline $\mathrm{Fe}-72.9 \mathrm{Al}$ & $\mathrm{AM}$ & As-cast & $\mathrm{Fe}_{2} \mathrm{Al}_{5}+\mathrm{Fe}_{4} \mathrm{Al}_{13}$ \\
\hline $\mathrm{Fe}-74.2 \mathrm{Al}$ & VIM & $\begin{array}{l}\text { As-cast } \\
600{ }^{\circ} \mathrm{C} / 5000 \mathrm{~h} \\
800{ }^{\circ} \mathrm{C} / 200 \mathrm{~h} \\
1000{ }^{\circ} \mathrm{C} / 100 \mathrm{~h} \\
1100{ }^{\circ} \mathrm{C} / 50 \mathrm{~h}\end{array}$ & $\begin{array}{l}\mathrm{Fe}_{4} \mathrm{Al}_{13} \\
\mathrm{Fe}_{2} \mathrm{Al}_{5}+\mathrm{Fe}_{4} \mathrm{Al}_{13}\end{array}$ \\
\hline $\mathrm{Fe}-74.5 \mathrm{Al}$ & LM & As-cast & $\mathrm{Fe}_{4} \mathrm{Al}_{13}$ \\
\hline $\mathrm{Fe}-74.9 \mathrm{Al}$ & VIM & $\begin{array}{l}\text { As-cast } \\
800{ }^{\circ} \mathrm{C} / 200 \mathrm{~h} \\
1000{ }^{\circ} \mathrm{C} / 100 \mathrm{~h}\end{array}$ & $\begin{array}{l}\mathrm{Fe}_{4} \mathrm{Al}_{13} \\
\mathrm{Fe}_{2} \mathrm{Al}_{5}+\mathrm{Fe}_{4} \mathrm{Al}_{13}\end{array}$ \\
\hline $\mathrm{Fe}-76.7 \mathrm{Al}$ & $\mathrm{AM}$ & As-cast & $\mathrm{Fe}_{4} \mathrm{Al}_{13}+\mathrm{Al}$ \\
\hline $\mathrm{Fe}-78.9 \mathrm{Al}$ & $\mathrm{AM}$ & As-cast & $\mathrm{Fe}_{4} \mathrm{Al}_{13}+\mathrm{Al}$ \\
\hline
\end{tabular}

Table 5 Solid-solid and solid-liquid Fe-50Al/Al diffusion couples and observed phase layers

\begin{tabular}{lll}
\hline Heat treatment condition & Diffusion couple type & \multicolumn{1}{c}{ Observed phase layers } \\
\hline $620{ }^{\circ} \mathrm{C} / 5 \mathrm{~h}$ under $\mathrm{Ar}$ & Solid-Solid & $\mathrm{FeAl} / \mathrm{Fe}_{2} \mathrm{Al}_{5} / \mathrm{Fe}_{4} \mathrm{Al}_{13} / \mathrm{Al}$ \\
$800{ }^{\circ} \mathrm{C} / 48 \mathrm{~h}$ under $\mathrm{Ar}$ & Solid-Liquid & $\mathrm{FeAl} / \mathrm{FeAl}_{2} / \mathrm{Fe}_{2} \mathrm{Al}_{5}$ \\
$850^{\circ} \mathrm{C} / 2 \mathrm{~h}$ under $\mathrm{Ar}$ & Solid-Liquid & $\mathrm{FeAl}_{\mathrm{FeAl}} / \mathrm{Fe}_{2} \mathrm{Al}_{5} / \mathrm{Fe}_{4} \mathrm{Al}_{13} / \mathrm{Al}$ \\
\hline
\end{tabular}

After heat treatment, in all cases precipitates of $\mathrm{Fe}_{2} \mathrm{Al}_{5}$ were found (Fig. $5 b$ ) in accordance with the phase diagram.

Figure 6 shows representative DTA heating curves for the Al-rich alloys with 67 to 79 at.\% Al, which were measured with a heating rate of $1{ }^{\circ} \mathrm{C} / \mathrm{min}$. All transition temperatures obtained from the DTA measurements are summarized in Table 6 . The transition temperatures were determined from the intersection point of the two tangents as shown at the onset of the peaks. This procedure follows the definition given by Höhne et al. ${ }^{[36,37]}$ Comparing the 

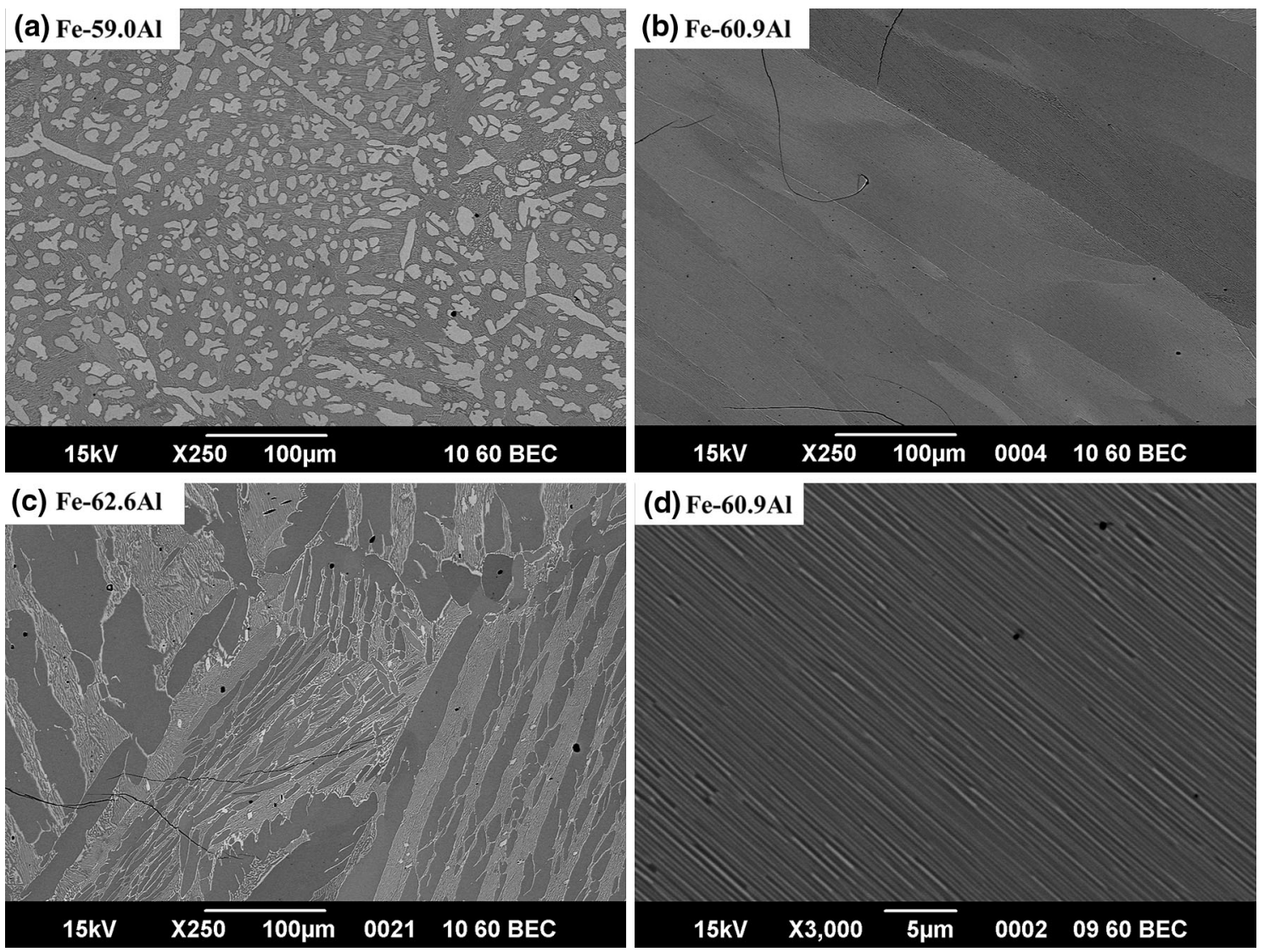

Fig. 2 SEM back-scattered electron (BSE) micrograph for the as-cast alloys (a) Fe-59.0Al, (b) Fe-60.9Al, and (c) Fe-62.6Al; (d) fully lamellar microstructure of Fe-60.9Al in high magnification ${ }^{[35]}$

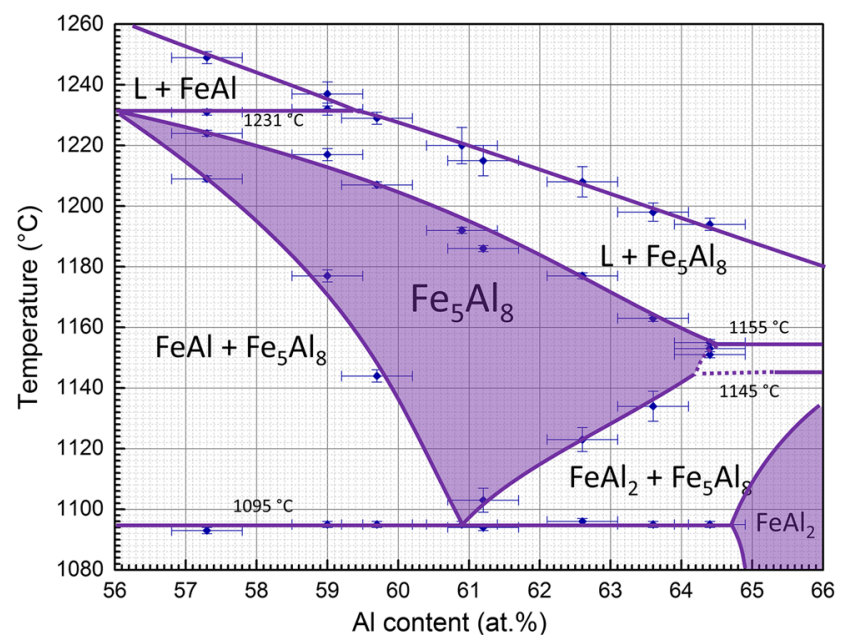

Fig. 3 Phase field of the high-temperature phase $\mathrm{Fe}_{5} \mathrm{Al}_{8}$ as determined by DTA

curves of the Fe-68.0Al and Fe-69.4Al samples, it is obvious that the peritectoid reaction peak of the dissolution of $\mathrm{FeAl}_{2}$ is missing in case of the Al-richer alloy. This indicates that the composition of the $\mathrm{Fe}_{2} \mathrm{Al}_{5}$ phase in the peritectoid reaction $\mathrm{Fe}_{5} \mathrm{Al}_{8}+\mathrm{Fe}_{2} \mathrm{Al}_{5} \leftrightarrow \mathrm{FeAl}_{2}$ is between 68.0 and 69.4 at.\% Al. While the eutectic/peritectic temperatures are clearly visible in the heating curves and can usually be determined with an accuracy of \pm 1 or $2{ }^{\circ} \mathrm{C}$, this is not the case for the liquidus temperatures due to the partially very small temperature intervals between solidus and liquidus. In order to get the correct values for the liquidus temperatures, they were determined according to a method described in detail in Ref 38 using both the heating and cooling curves. Nonetheless, the accuracy of some of the determined liquidus values is only $\pm 4{ }^{\circ} \mathrm{C}$. Therefore, the DTA data are not adequate to exclude definitely the existence of a eutectic point near 75 to 76 at.\% Al. As such a eutectic composition would be inside the homogeneity range of $\mathrm{Fe}_{4} \mathrm{Al}_{13}$ at intermediate temperatures (see final phase diagram in Fig. 10), the eutectic microstructure would not be visible at room temperature. On the basis of all DTA results, the high-temperature part of the phase diagram between 65 and 80 at.\% Al was drawn as shown in Fig. 7.

\subsection{Homogeneity Ranges of $\mathrm{FeAl}_{2}, \mathrm{Fe}_{2} \mathrm{Al}_{5}$, and $\mathrm{Fe}_{4} \mathrm{Al}_{13}$}

In order to study the equilibrium compositions and homogeneity ranges of all phases concerned, heat treatments in the range of 600 to $1100{ }^{\circ} \mathrm{C}$ were performed as is listed in Table 4 . The resulting equilibrium phase compositions are 

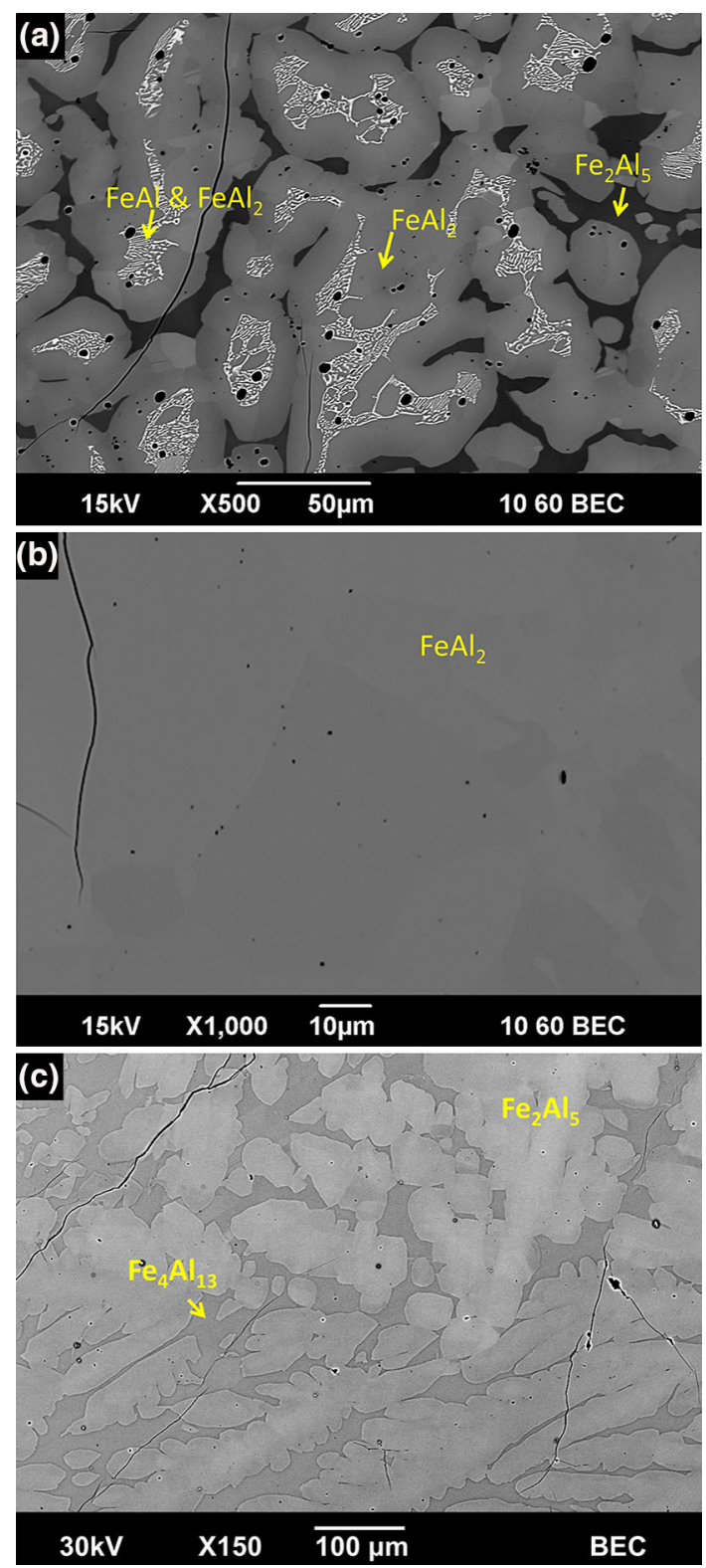

Fig. 4 SEM-BSE micrographs of Fe-66.8Al in the (a) as-cast and (b) heat-treated $\left(900^{\circ} \mathrm{C} / 840 \mathrm{~h}\right)$ state, and of (c) alloy Fe$72.9 \mathrm{Al}$ in as-cast state

given in Table 7 . In addition, the occurring phases and their lattice parameters were studied by XRD. As an example, Fig. 8 shows a comparison of the XRD patterns of as-cast and heat-treated $\left(800{ }^{\circ} \mathrm{C} / 200 \mathrm{~h}\right) \mathrm{Fe}-69.4 \mathrm{Al}$. In the as-cast state only the peaks characteristic for the crystal structure of $\mathrm{Fe}_{2} \mathrm{Al}_{5}$ are visible, while after the heat treatment the reflections of both $\mathrm{FeAl}_{2}$ and $\mathrm{Fe}_{2} \mathrm{Al}_{5}$ can be clearly detected in good agreement with the microstructural observations (see Table 4). The lattice parameters obtained from some selected heat-treated alloys are listed in Table 8. As expected, the unit cell volume of a certain phase increases with increasing $\mathrm{Al}$ content due to the larger atomic size of Al compared to Fe.
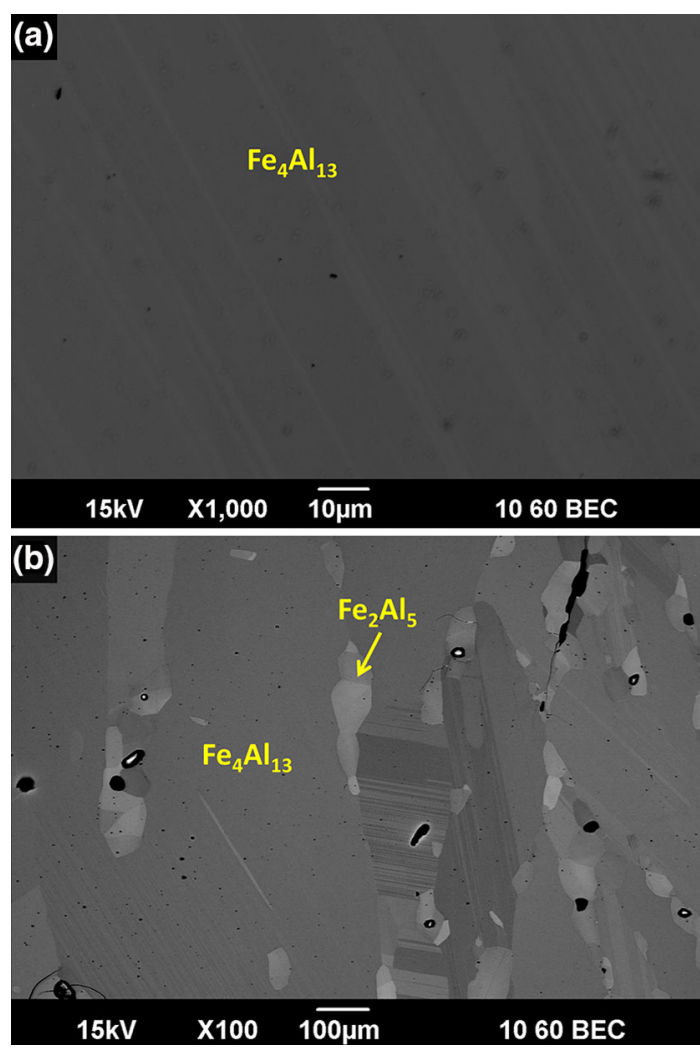

Fig. 5 SEM-BSE micrographs of Fe-74.2Al in the (a) as-cast and (b) heat-treated $\left(1000^{\circ} \mathrm{C} / 100 \mathbf{h}\right)$ state

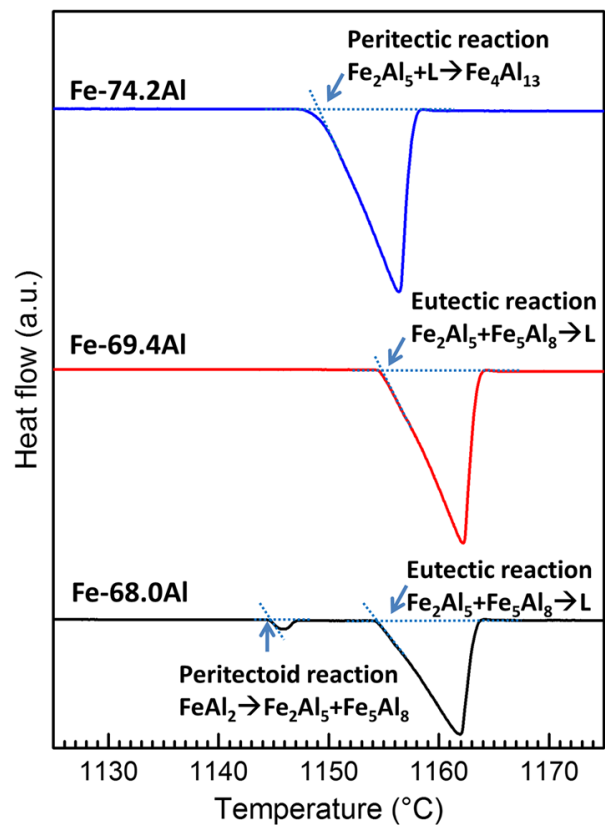

Fig. 6 DTA heating curves $\left(1{ }^{\circ} \mathrm{C} / \mathrm{min}\right)$ of as-cast $\mathrm{Fe}-68.0 \mathrm{Al}$, $\mathrm{Fe}-69.4 \mathrm{Al}$ and Fe-74.2Al 
Table 6 Transition temperatures of the investigated alloys (67-79 at.\% Al) as obtained from DTA measurements (the numbers given in parentheses notify the accuracy of the respective values)

\begin{tabular}{|c|c|c|c|}
\hline \multirow[b]{2}{*}{ Alloy } & \multicolumn{3}{|c|}{ Reaction temperature, ${ }^{\circ} \mathrm{C}$} \\
\hline & Peritectoid reactionFeAl $\mathrm{A}_{2} \leftrightarrow \mathrm{Fe}_{2} \mathrm{Al}_{5}+\mathrm{Fe}_{5} \mathrm{Al}_{8}$ & Eutectic reactionL $\leftrightarrow \mathrm{Fe}_{2} \mathrm{Al}_{5}+\mathrm{Fe}_{5} \mathrm{Al}_{8}$ & Liquidus temperature \\
\hline $\mathrm{Fe}-66.8 \mathrm{Al}$ & $1145(1)$ & $1156(2)$ & $1167(4)$ \\
\hline $\mathrm{Fe}-68.0 \mathrm{Al}$ & $1145(1)$ & 1155(1) & $1159(3)$ \\
\hline $\mathrm{Fe}-69.4 \mathrm{Al}$ & $\ldots$ & 1155(1) & $1158(4)$ \\
\hline \multirow[t]{2}{*}{$\mathrm{Fe}-70.3 \mathrm{Al}$} & $\ldots$ & $1156(1)$ & $1158(2)$ \\
\hline & & $\left(\mathrm{Fe}_{2} \mathrm{Al}_{5} \leftrightarrow \mathrm{L}+\mathrm{Fe}_{2} \mathrm{Al}_{5}\right)$ & \\
\hline
\end{tabular}

\begin{tabular}{lccc}
\hline & Eutectic reactionL $\leftrightarrow \mathbf{F e}_{\mathbf{4}} \mathbf{A} \mathbf{l}_{\mathbf{1 3}}+\mathbf{A l}$ & Peritectic reactionL $+\mathbf{F e}_{\mathbf{2}} \mathbf{A} \mathbf{I}_{\mathbf{5}} \leftrightarrow \mathbf{F e}_{\mathbf{4}} \mathbf{A} \mathbf{l}_{\mathbf{1 3}}$ & Liquidus temperature \\
\hline $\mathrm{Fe}-71.7 \mathrm{Al}$ & $\ldots$ & $1150(1)$ & $1157(3)$ \\
$\mathrm{Fe}-72.9 \mathrm{Al}$ & $\ldots$ & $1151(1)$ & $1154(4)$ \\
$\mathrm{Fe}-74.2 \mathrm{Al}$ & $\ldots$ & $1150(1)$ & $1153(4)$ \\
$\mathrm{Fe}-74.5 \mathrm{Al}$ & $\ldots$ & $1150(1)$ & $1153(4)$ \\
$\mathrm{Fe}-74.9 \mathrm{Al}$ & $\ldots$ & $1149(1)$ & $1152(4)$ \\
$\mathrm{Fe}-76.7 \mathrm{Al}$ & $653(1)$ & $\ldots$ & $1150(3)$ \\
$\mathrm{Fe}-78.9 \mathrm{Al}$ & $654(1)$ & $\ldots$ & $1136(3)$ \\
\hline
\end{tabular}

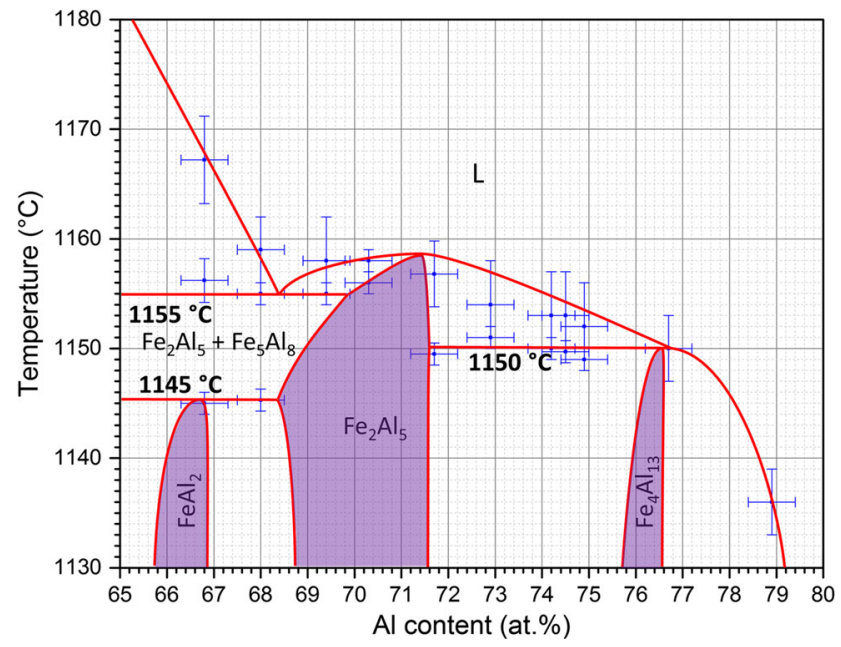

Fig. 7 Redetermination of the Fe-Al phase diagram in the Alrich composition range at high temperatures above $1130{ }^{\circ} \mathrm{C}$

As already mentioned in the section 2, in addition to heat-treated alloys of fixed compositions, three diffusion couples between $\mathrm{Fe}-50 \mathrm{Al}$ and pure $\mathrm{Al}$ were used for determining equilibrium phase compositions and homogeneity ranges of the intermetallic phases (Table 5). This method takes advantage of the local equilibrium existing at the phase interfaces. The concentration profiles resulting from the heat treatments were measured by EPMA with step widths of $1 \mu \mathrm{m}$. As an example, Fig. 9(a) shows the microstructure with the resulting diffusion zones of the different intermetallic phases in the diffusion couple heattreated at $850{ }^{\circ} \mathrm{C}$, and in Fig. 9(b) and (c) one of the concentration profiles measured along the marked line is

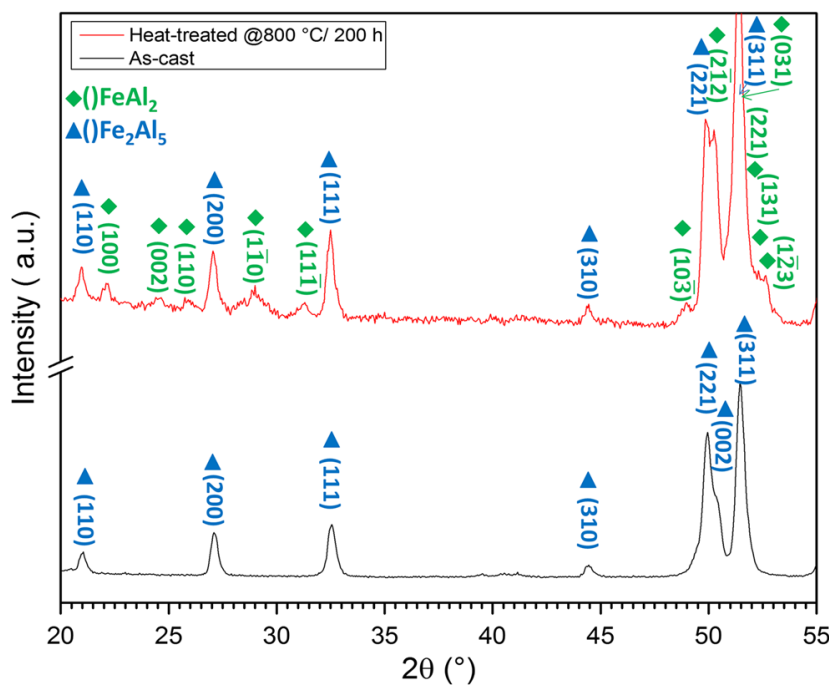

Fig. 8 Low-angle part of the XRD pattern of as-cast and heattreated $\left(800{ }^{\circ} \mathrm{C} / 200 \mathrm{~h}\right) \mathrm{Fe}-69.4 \mathrm{Al}(\mathrm{Co}-\mathrm{K} \alpha$ radiation)

plotted. The profile clearly shows the jumps in concentration between the four intermetallic phases $\mathrm{FeAl}, \mathrm{FeAl}_{2}, \mathrm{Fe}_{2} \mathrm{Al}_{5}$, and $\mathrm{Fe}_{4} \mathrm{Al}_{13}$ as well as pure $\mathrm{Al}$, and from extrapolations to the interfaces, the equilibrium compositions of the phases can be obtained. The results are included in Table 7. The growth kinetics of the intermetallic phases differs very much from each other. As is well-known from the literature and nicely confirmed in Fig. 9(a), $\mathrm{Fe}_{2} \mathrm{Al}_{5}$ grows much quicker than the other phases, and $\mathrm{FeAl}_{2}$ often grows so slowly that it is hardly visible or totally missing. This happened in case of the present solid-solid diffusion couple $\left(620{ }^{\circ} \mathrm{C}\right.$ for $\left.5 \mathrm{~h}\right)$, where the concentration directly jumps from that of $\mathrm{FeAl}$ to $\mathrm{Fe}_{2} \mathrm{Al}_{5}$. 
Table 7 Equilibrium phase compositions as obtained from EPMA analysis of heat-treated samples (HT) and diffusion couples (DC), accuracy is \pm 0.5 at. $\%$

\begin{tabular}{|c|c|c|c|c|c|c|c|c|c|}
\hline$T,{ }^{\circ} \mathrm{C}$ & Method & $\begin{array}{l}\text { FeAl (Al-rich) } \\
\text { at.\% Al }\end{array}$ & $\mathrm{FeAl}_{2}$ (Al-lean) & $\mathrm{FeAl}_{2}$ (Al-rich) & $\mathrm{Fe}_{2} \mathrm{Al}_{5}$ (Al-lean) & $\mathrm{Fe}_{2} \mathrm{Al}_{5}$ (Al-rich) & $\mathrm{Fe}_{4} \mathrm{Al}_{13}$ (Al-lean) & $\mathrm{Fe}_{4} \mathrm{Al}_{13}$ (Al-rich) & Al \\
\hline 1100 & HT & $\ldots$ & $\ldots$ & 66.4 & 69.2 & $\ldots$ & $\ldots$ & $\ldots$ & $\ldots$ \\
\hline 1000 & HT & 51.8 & 64.9 & 66.7 & 70.0 & 72.5 & 74.6 & $\ldots$ & $\ldots$ \\
\hline 900 & HT & 51.5 & 65.3 & $\ldots$ & $\ldots$ & $\ldots$ & $\ldots$ & $\ldots$ & $\ldots$ \\
\hline 850 & DC & 50.9 & 65.5 & 66.8 & 70.2 & 72.9 & 76.5 & 76.9 & $\ldots$ \\
\hline \multirow[t]{2}{*}{800} & HT & 51.8 & 65.9 & 66.8 & 69.9 & 72.8 & 75.6 & $\ldots$ & $\ldots$ \\
\hline & $\mathrm{DC}$ & 51.7 & 65.6 & 66.9 & 70.1 & $\ldots$ & $\ldots$ & $\ldots$ & $\ldots$ \\
\hline 620 & DC & 49.2 & $\ldots$ & $\ldots$ & 69.9 & 72.5 & $(76.4)(a)$ & $(76.5)(a)$ & 99.8 \\
\hline 600 & HT & 52 & 65.2 & 66.7 & 70.7 & 73.1 & 76.3 & $\ldots$ & $\ldots$ \\
\hline
\end{tabular}

If there are at least two values for same heat treatment or diffusion couple condition, only the average value is given in table. (a) Very thin diffusion layer

Table 8 Lattice parameters of intermetallic phases in representative heat-treated alloys as obtained from powder XRD ('vol' means the volume of the unit cell)

\begin{tabular}{|c|c|c|c|c|}
\hline \multirow[b]{2}{*}{ Alloy } & \multicolumn{4}{|c|}{ Phase } \\
\hline & FeAl & $\mathrm{FeAl}_{2}$ & $\mathrm{Fe}_{2} \mathrm{Al}_{5}$ & $\mathrm{Fe}_{4} \mathrm{Al}_{13}$ \\
\hline $\begin{array}{r}\mathrm{Fe}-62.6 \mathrm{Al} \\
1000^{\circ} \mathrm{C} / 6 \mathrm{~h}\end{array}$ & $\begin{array}{c}51.7(5) \text { at. } \% \mathrm{Al} \\
a=0.2906(4) \mathrm{nm} \\
\text { vol }=0.245(1) \mathrm{nm}^{3}\end{array}$ & 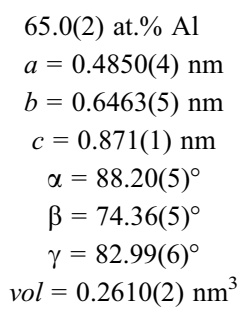 & $\ldots$ & $\ldots$ \\
\hline $\begin{array}{c}\mathrm{Fe}-69.4 \mathrm{Al} \\
800^{\circ} \mathrm{C} / 200 \mathrm{~h}\end{array}$ & $\ldots$ & 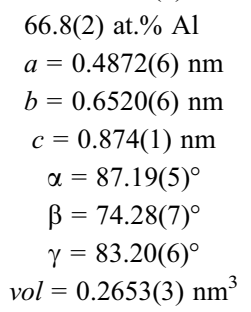 & $\begin{array}{c}70.3(1) \text { at. } \% \mathrm{Al} \\
a=0.7647(3) \mathrm{nm} \\
b=0.6414(3) \mathrm{nm} \\
c=0.4208(2) \mathrm{nm} \\
\text { vol }=0.2064(1) \mathrm{nm}^{3}\end{array}$ & $\ldots$ \\
\hline $\begin{array}{c}\mathrm{Fe}-74.2 \mathrm{Al} \\
800^{\circ} \mathrm{C} / 200 \mathrm{~h}\end{array}$ & $\ldots$ & $\ldots$ & $\begin{array}{c}72.8 \pm 0.2 \text { at. } \% \mathrm{Al} \\
a=0.7657(2) \mathrm{nm} \\
b=0.6404(2) \mathrm{nm} \\
c=0.4229(1) \mathrm{nm} \\
v o l=0.20739(6) \mathrm{nm}^{3}\end{array}$ & $\begin{array}{l}75.8 \pm 0.1 \text { at. } \% \mathrm{Al} \\
a=1.5496(5) \mathrm{nm} \\
b=0.8052(6) \mathrm{nm} \\
\begin{array}{c}c=1.2477(8) \mathrm{nm} \\
\beta=107.69(4)^{\circ} \\
\text { vol }=1.483(1) \mathrm{nm}^{3}\end{array}\end{array}$ \\
\hline
\end{tabular}




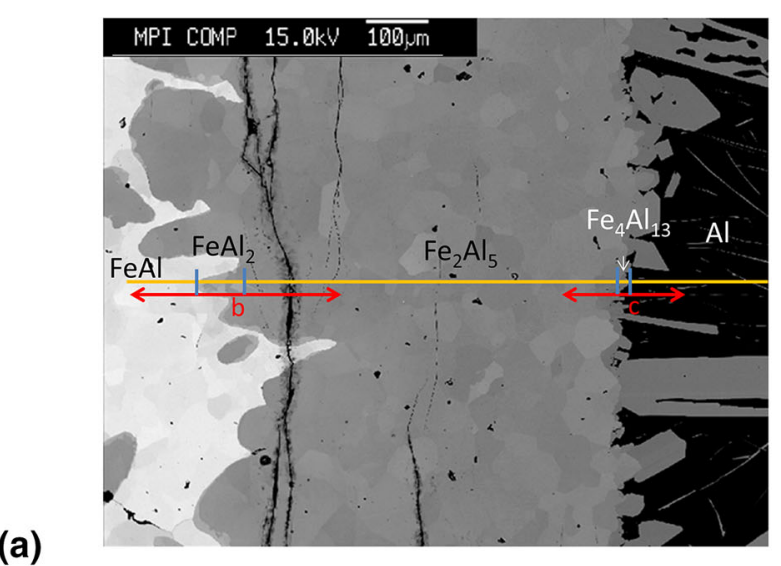

(a)
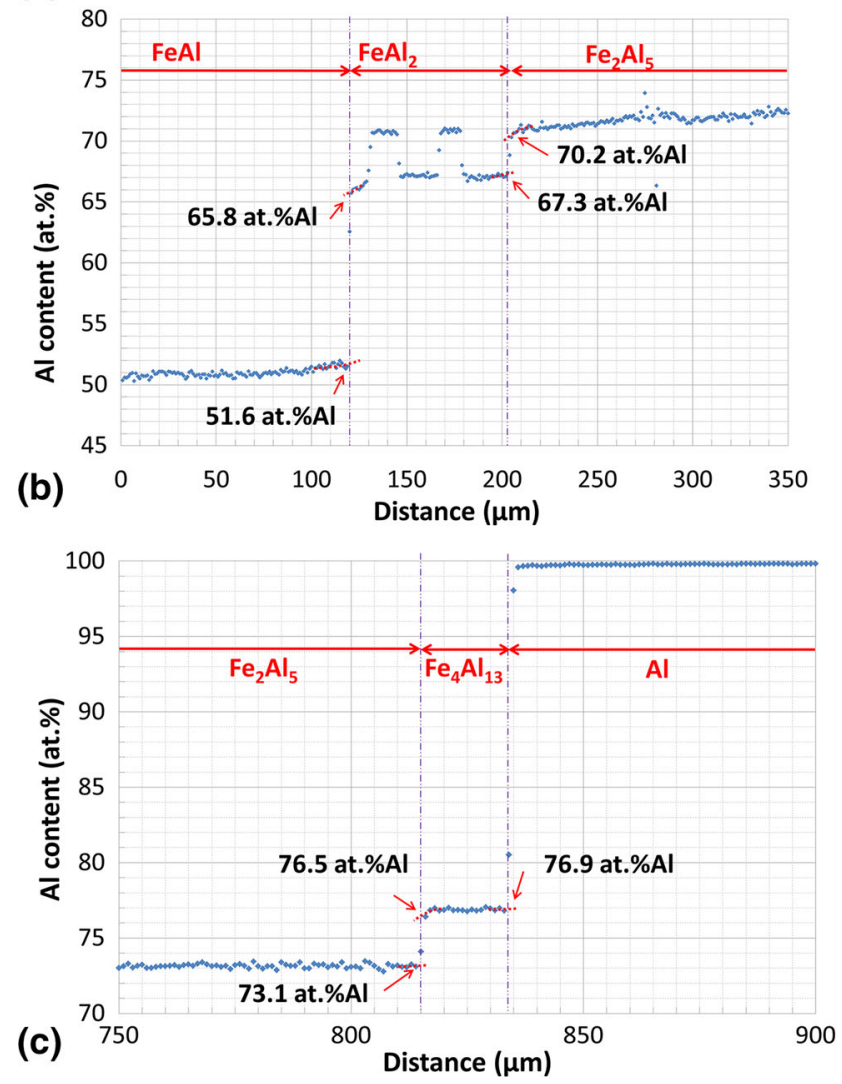

Fig. 9 (a) SEM-BSE micrograph of the diffusion layers and (bc) variation of $\mathrm{Al}$ content across $\mathrm{Fe}-50 \mathrm{Al} / \mathrm{Al}$ solid-liquid diffusion couple interface obtained by EPMA for sample annealed at $850^{\circ} \mathrm{C}$ for $2 \mathrm{~h}$

\section{Conclusions}

Figure 10 shows a revised version of the Al-rich part of the Fe-Al phase diagram as obtained from a combination of all results from phase analysis in heat-treated alloys and diffusion couples, investigation of as-cast and heat-treated microstructures, and determination of liquidus, solidus, and invariant reaction temperatures.

The main results can be summarized as follows:

1. The homogeneity range of $\mathrm{Fe}_{5} \mathrm{Al}_{8}$ phase extends from 56.0 to 64.4 at. $\%$ Al. At the low-Al side, it ends in the peritectic reaction $\mathrm{L}+\mathrm{FeAl} \leftrightarrow \mathrm{Fe}_{5} \mathrm{Al}_{8}$ at $1231^{\circ} \mathrm{C}$ and the Al-rich side in the peritectoid reaction $\mathrm{Fe}_{2} \mathrm{Al}_{5}+\mathrm{Fe}_{5} \mathrm{Al}_{8} \leftrightarrow \mathrm{FeAl}_{2}$ at $1145^{\circ} \mathrm{C}$. The eutectoid reaction $\mathrm{Fe}_{5} \mathrm{Al}_{8} \leftrightarrow \mathrm{FeAl}_{2}+\mathrm{FeAl}$ is confirmed to occur at $1095{ }^{\circ} \mathrm{C}$ and the composition of the eutectoid point is 60.9 at. $\% \mathrm{Al}$.

2. The eutectic reaction $\mathrm{L} \leftrightarrow \mathrm{Fe}_{5} \mathrm{Al}_{8}+\mathrm{Fe}_{2} \mathrm{Al}_{5}$ occurs at $1155^{\circ} \mathrm{C} . \mathrm{Fe}_{2} \mathrm{Al}_{5}$ forms congruently from the liquid at 71.4 at.\% $\mathrm{Al}$ and an estimated temperature of $1159{ }^{\circ} \mathrm{C} . \mathrm{Fe}_{4} \mathrm{Al}_{13}$ forms at $1150{ }^{\circ} \mathrm{C}$. The reaction most likely is of the peritectic type $\left(\mathrm{L}+\mathrm{Fe}_{2} \mathrm{Al}_{5} \leftrightarrow\right.$ $\left.\mathrm{Fe}_{4} \mathrm{Al}_{13}\right)$ with the peritectic point very near to the $\mathrm{Fe}_{4} \mathrm{Al}_{13}$ composition, but for the present data it cannot be finally excluded that the reaction is congruent.

3. At $800{ }^{\circ} \mathrm{C}, \mathrm{Fe}_{4} \mathrm{Al}_{13}$ has a very narrow homogeneity range of about 0.5 at.\%, the $\mathrm{Fe}_{2} \mathrm{Al}_{5}$ phase extends from 70.0 to 72.6 at. $\% \mathrm{Al}$, and $\mathrm{FeAl}_{2}$ from 65.8 to 67.1 at. $\%$ Al. At $1000{ }^{\circ} \mathrm{C}$, the widths of homogeneity ranges of $\mathrm{FeAl}_{2}, \mathrm{Fe}_{2} \mathrm{Al}_{5}$, and $\mathrm{Fe}_{4} \mathrm{Al}_{13}$ are 2.0, 2.5, and 1.0 at.\%, respectively. At the Al-rich end of the phase diagram, the eutectic reaction $\mathrm{L} \leftrightarrow \mathrm{Fe}_{4} \mathrm{Al}_{13}+\mathrm{Al}$ is determined to occur at $654{ }^{\circ} \mathrm{C}$, which agrees well with all reported literature values. 


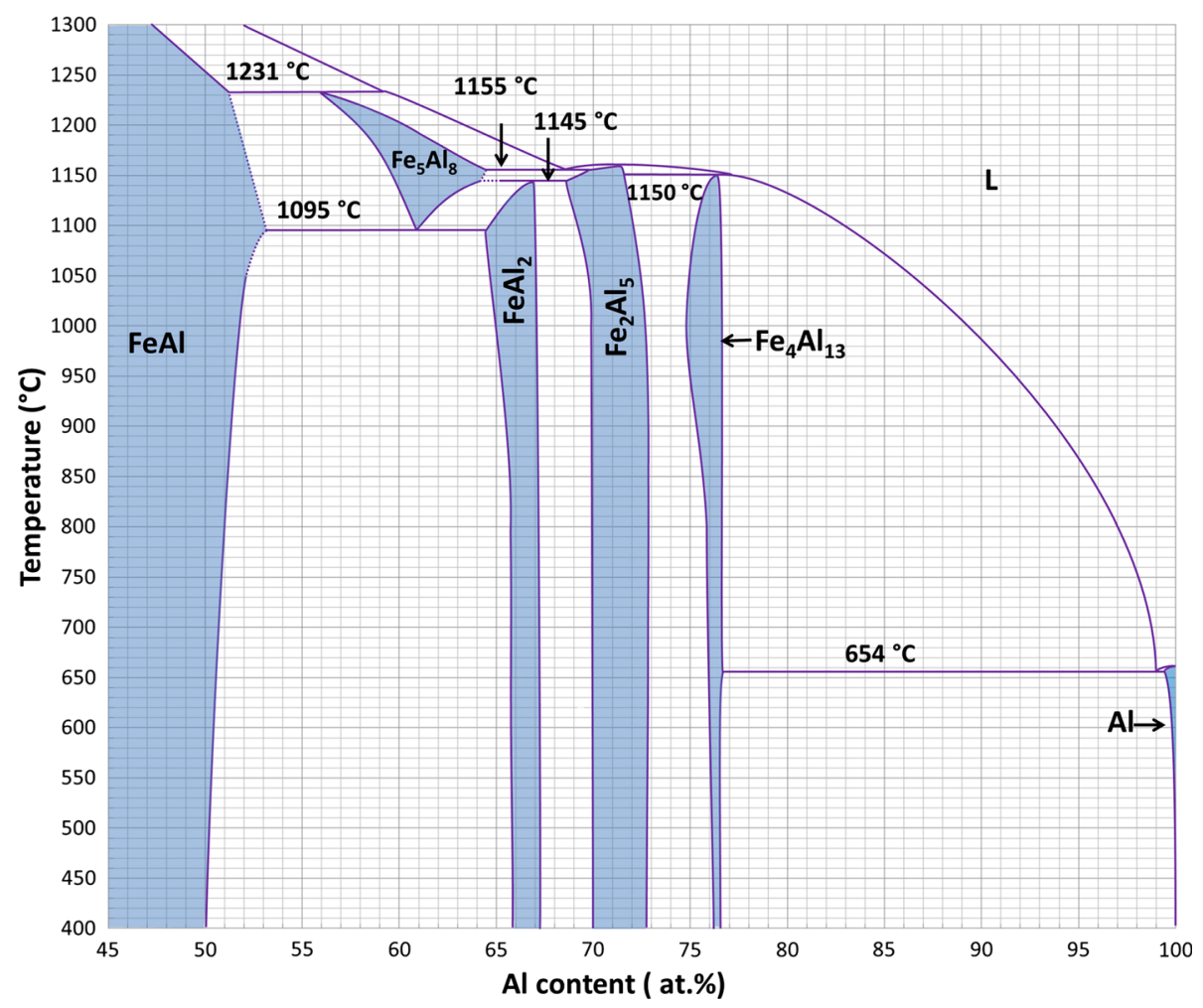

Fig. 10 Al-rich part of the Fe-Al phase diagram as obtained from the present investigations

\section{Acknowledgment}

Open access funding provided by Max Planck Society (or associated institution if applicable). The authors would like to thank Mr. G. Bialkowski for cutting samples for microstructure investigation and DTA specimens by EDM, Mr. B. Breitbach for XRD measurements, and Mrs. I. Wossack for EPMA. The financial support by the Deutsche Forschungsgemeinschaft is gratefully acknowledged.

\section{Open Access}

This article is distributed under the terms of the Creative Commons Attribution 4.0 International License (http:// creativecommons.org/licenses/by/4.0/), which permits unrestricted use, distribution, and reproduction in any medium, provided you give appropriate credit to the original author(s) and the source, provide a link to the Creative Commons license, and indicate if changes were made.

\section{References}

1. N.S. Stoloff, Iron Aluminides-Present Status and Future Prospects, Mater. Sci. Eng. A, 1998, 258, p 1-14

2. M. Palm, Fe-Al Materials for Structural Applications at High Temperatures: Current Research at MPIE, Int. J. Mater. Res., 2009, 100, p 277-287

3. D.G. Morris and M.A. Morris-Munoz, Recent Developments Toward the Application of Iron Aluminides in Fossil Fuel Technologies, Adv. Eng. Mater., 2011, 13, p 43-47
4. P. Villars and L.D. Calvert, Pearson's Handbook of Crystallographic Data for Intermetallic Phases, 2nd ed., ASM Int, Materials Park, OH, 1991

5. F. Stein, S.C. Vogel, M. Eumann, and M. Palm, Determination of the Crystal Structure of the $\varepsilon$ Phase in the Fe-Al System by High-Temperature Neutron Diffraction, Intermetallics, 2010 , 18, $\mathrm{p} 150-156$

6. S.C. Vogel, F. Stein, and M. Palm, Investigation of the $\varepsilon$ Phase in the Fe-Al System by High-Temperature Neutron Diffraction, Appl. Phys. A, 2010, 99, p 607-611

7. I. Chumak, K.W. Richter, and H. Ehrenberg, Determination of Iron Dialuminde, $\mathrm{FeAl}_{2}$, Acta Cryst. C, 2010, 66, p i87-i88

8. U. Burkhardt, Yu. Grin, M. Ellner, and K. Peters, Structure Refinement of the Iron-Aluminium Phase with the Approximate Composition $\mathrm{Fe}_{2} \mathrm{Al}_{5}$, Acta Cryst. B, 1994, 50, p 313-316

9. J. Grin, U. Burkhardt, M. Ellner, and K. Peters, Refinement of the $\mathrm{Fe}_{4} \mathrm{Al}_{13}$ Structure and Its Relationship to the Quasihomological Homeotypical Structures, Z. Kristallogr., 1994, 209, p 479-487

10. P.J. Black, The Structure of $\mathrm{FeAl}_{3}$. I and II, Acta Crystallogr., $1955,8, p$ 43-48 and $175-182$

11. A.G.C. Gwyer, Alloys of Aluminum with Copper Iron, Nickel, Cobalt, Lead and Cadmium, Z. Anorg. Chem., 1908, 57, p 113-153

12. N. Kurnakow, G. Urasow, and A. Grigorjew, Legierungen des Eisens mit Aluminium, Z. Anorg. Chem., 1922, 125, p 207227

13. M. Isawa and T. Murakami, On the Equilibrium Diagram of Iron-Almunium System, Kinzoku no kenkyu, 1927, 4, p 467-477

14. A.G.C. Gwyer and H.W.L. Phillips, The Constitution of Alloys of Aluminum with Silicon and Iron, J. Inst. Met., 1927, 38, p 29-83 
15. N.W. Ageew and O.I. Vher, The Diffusion of Aluminium into Iron, J. Inst. Met., 1930, 44, p 83-96

16. A. Osawa, On the Equilibrium Diagram of Iron-Aluminium System, Sci. Rep. Tohoku Univ., 1933, 22, p 803-823

17. A.J. Bradley and A. Taylor, An X-ray Investigation of Aluminium-Rich Iron-Nickel-Aluminium Alloys After Slow Cooling, J. Inst. Met., 1940, 66, p 53-65

18. E. Gebhardt and W. Obrowski, Reactions of Solid Iron with Melts of Aluminium and Aluminium Alloys, Z. Metallkd., 1953, 44, p 154-160

19. J.R. Lee, Liquidus-Solidus Reactions in the System IronAluminium, J. Iron steel Inst., 1960, 194, p 222-224

20. F. Honda and $\mathrm{K}$. Horikawa, Isolation of the Intermetallic Compounds $\mathrm{Al}_{2} \mathrm{Cu}, \mathrm{Al}_{12} \mathrm{Mg}_{17}, \mathrm{Al}_{3} \mathrm{Fe}, \mathrm{Al}_{9} \mathrm{Co}_{2}$ and $\mathrm{Al}_{3} \mathrm{Ni}$ in Binary Aluminium Alloys by Application of an Organic Solvent, Z. Anal. Chem., 1972, 262, p 170-179

21. E. Schürmann and H.-P. Kaiser, Contribution to the Melting Equilibria of Iron-Aluminum and Iron-Phosphorus Alloys, Arch. Eisenhuettenwes, 1980, 51, p 325-327

22. A. Lendvai, The Phase Diagram of the Al-Fe System up to 45 Mass\% Iron, Thermochim. Acta, 1985, 93, p 681-684

23. A. Lendvai, Phase Diagram of the Al-Fe System up to 45 Mass\% Iron, J. Mater. Sci., 1986, 5, p 1219-1220

24. A. Griger, V. Stefániay, and T. Turmezey, Crystallographic Data and Chemical Compositions of Aluminium-Rich Al-Fe Intermetallic Phase, Z. Metallkd., 1986, 77, p 30-35

25. O. Kubaschewski, Iron-Binary Phase Diagrams, Springer, Berlin, 1982, p 5

26. U.R. Kattner and B.P. Burton, Phase Diagrams of Binary Iron Alloys, ASM International, Materials Park, OH, 1992, p 12

27. U. Burkhardt, M. Ellner, J. Grin, H. Ipser, K. Richter, J. Schuster, and F. Weitzer, Iron-Aluminium, in: AluminiumTransition Metal Phase Diagrams. Final Report International Workshop, Graz, Austria, May 1997, 1998, p 54-58

28. M. Turchanin, N. Kolchugina, A. Watson, and A. Kroupa, AlFe Binary Phase Diagram Evaluation, MSI Eureka, Evaluation Report 20.10236.1.8 (2013) MSI Materials Science International Services $\mathrm{GmbH}$
29. F. Stein and M. Palm, Re-determination of Transition Temperatures in the Fe-Al System by Differential Thermal Analysis, Int. J. Mater. Res., 2007, 98, p 580-588

30. M. Seierstein, System Al-Fe, in: I. Ansara, A.T. Dinsdale, M.H. Rand, Eds., EUR 18499 (COST 507, Thermochemical Database for Light Metal Alloys), Vol 2, Office Official Public European Commission, Luxembourg, 1998, p 34-39

31. Y. Du, J.C. Schuster, Z.K. Liu, R. Hu, P. Nash, W. Sun, W. Zhang, J. Wang, L. Zhang, C. Tang, Z. Zhu, S. Liu, Y. Ouyang, W. Zhang, and N. Krendelsberger, A Thermodynamic Description of the Al-Fe-Si System over the Whole Composition and Temperature Ranges Via a Hybrid Approach of CALPHAD and Key Experiments, Intermetallics, 2008, 16, p 554-570

32. B. Sundman, I. Ohnuma, N. Dupin, U.R. Kattner, and S.G. Fries, An Assessment of the Entire Al-Fe System Including $\mathrm{DO}_{3}$ Ordering, Acta Mater., 2009, 57, p 2896-2908

33. M.H.G. Jacobs and R. Schmid-Fetzer, Phase Behavior and Thermodynamic Properties in the System Fe-Al, Calphad, 2009, 33, p 170-178

34. F. Stein, G. Sauthoff, and M. Palm, Phases and Phase Equilibria in the Fe-Al-Zr System, Z. Metallkd., 2004, 95, p 469-485

35. X. Li, M. Palm, A. Scherf, D. Janda, M. Heilmaier, and F. Stein, Microstructure and Phase Transformation Temperatures of Two-Phase FeAl (B2) + $\mathrm{FeAl}_{2}$ Alloys, MRS Proceedings, 2015, 1760, mrsf14-1760-yy04-09

36. G.W.H. Höhne, H.K. Cammenga, W. Eysel, E. Gmelin, and W. Hemminger, The Temperature Calibration of Differential Scanning Calorimeters, Thermochim. Acta, 1990, 160, p 1-12

37. G.W.H. Höhne, Remarks on the Calibration of Differential Scanning Calorimeters, J. Therm. Anal., 1991, 37, p 19872000

38. F. Stein, C. He, and N. Dupin, Melting Behaviour and Homogeneity Range of B2 CoAl and Updated Thermodynamic Description of the Al-Co System, Intermetallics, 2013, 39, p 58-68 